\title{
Popper's Epistemology versus Popper's Politics: A Libertarian Viewpoint
}

\section{J C Lester}

What is my thesis? It is not that radical experimentation by the state, rather than liberal democracy, is more in accord with the spirit and logic of Popper's 'revolutionary' epistemology. It is the opposite criticism, that full anarchic libertarianism (individual liberty and the free market without any state interference) better fits Popper's epistemology and scientific method.

I think this thesis important because I accept Popper's epistemology and methodology, and I think that these are a useful part of the defense of libertarianism: the value of complete liberty is a bold conjecture that withstands criticism rather than a theory to be supported by any specific argument or set of arguments. And, in its turn, libertarianism is a useful part of the defense of Popper's epistemology and methodology: it illustrates their beneficial social applications. In one sense, Popper's picture of the best way to pursue truth is only a part of the more general picture of libertarianism. Popper advocates what can be called 'intellectual libertarianism'. I am here suggesting that his libertarianism should be extended to the realm of individual persons and businesses (as contractual organizations, but I do not mean to exclude other voluntary organizations). Popper writes that he seeks to put 'the finishing touches to Kant's own critical philosophy' ([1963] 1978, 27). I seek to put the finishing touches to Popper's own social philosophy.

Let us briefly recapitulate Popper's scientific epistemology and methodology. As Hume showed, it is logically impossible to support a universal theory with evidence. All corroborating evidence, even if accurate, is an infinitely small proportion of what the theory predicts. But one counterexample shows a universal theory to be false. Thus the only rational way to pursue truth is to conjecture without supporting evidence and then deliberately to seek refutation. The bolder the conjecture (compatible with background knowledge), the greater the chance of capturing more truth. ${ }^{1}$ A free scientific culture is more or less a libertarian anarchy: anyone can form a theory and test it, and the results can be accepted, further tested, rejected, or ignored by other individual scientists. Laypeople tend to hear mostly about theories on which there is a scientific consensus and so do not always perceive the diversity and competition in science.

There are similarities with the anarchic workings of individual liberty and the free market. Anyone can originate a practice or product. People have individually to choose to try such practices or buy such products. Social and individual practices are aimed at satisfaction. They increase immediate utility or at least are useful experimentation. A new product offered by the individual entrepreneur is analogous with the bold new theories of the individual scientist. Analogous with having scientific theories aimed at truth, consumer products are aimed to satisfy demand..$^{2}$

By contrast, 'liberal democracies' illiberally ban and mandate various practices and products in a way that tends not to happen in science (unless the state intervenes). Unlibertarian regulation of social and personal practices decreases immediate utility or useful experimentation. Such policies as state subsidies to failing businesses and import restrictions that 'protect' domestic production are analogous with ad hoc defenses of a theory (here in the form of a product) instead of accepting the 'falsification' that is the absence of consumer demand.

If the scientific community were run democratically, then it would be as great a disaster for the discovery of truth as democracy is a disaster for the promotion of liberty and welfare. Michael Polanyi (1951) shows the deleterious effects on science of greater state regulation. Full blown democracy could only be more severe for science.

Popper sees that the people 'never rule themselves in any concrete, practical sense' ([1945] 1977, 1: 125). His understanding of 'democracy' is not rule by the people but rather a way of limiting bad rule, ultimately in order to preserve maximum equal 'freedom' - or so he asserts. But from a libertarian viewpoint, liberal democracy is a practical contradiction (at least, to the extent that 'liberal' means having respect for interpersonal liberty): the more liberty individuals have the less they can be ruled by 'the people' (or anyone else). A liberal democracy is a sort of substitute for all-out civil war. The winning side imposes its rules on the others by force and the threat of force. The taxation and regulation of people who are not imposing on anyone are themselves forms of aggressive imposition rather than peaceful persuasion. Popper insists that 
'any kind of freedom is clearly impossible unless it is guaranteed by the state' ([1945] 1977, 1: 111). The possibility of competing private police and courts protecting persons and their property and of anarchic defense are beyond rational consideration for Popper. ${ }^{3}$

He writes that the question "Who should rule?" ... begs for an authoritarian answer' ([1963] 1978, 25). Libertarians disagree. 'Each should rule himself: a sovereign individual' is a coherent non-authoritarian answer. Popper prefers to ask, 'How can we organise our political institutions so that bad or incompetent rulers ... cannot do too much damage?' ([1963] 1978, 25). But this clearly does presuppose the necessity for political authority over subjects. The very possibility of individual sovereignty, rather than the 'institutional control of the rulers', is also 'thereby eliminated without ever having been raised' ([1945] 1977, 1: 126). And with libertarianism, analogously with Popper's defense of good democratic institutions, the institution of individual sovereignty would ipso facto be maximally spread for safety.

I am interested only in what I call 'actually existing democracy' rather than some impossible ideal (just as people used to refer to 'actually existing socialism' - meaning regimes calling themselves 'socialist' - rather than some impossible ideal of socialism). I mention this because Popper often explicitly sees some unfortunate state of affairs but he fails to see that it is practically intrinsic to liberal democracy. In fact he goes so far as to assert that it is 'quite wrong to blame democracy for the political shortcomings of a democratic state. We should rather blame ourselves, that is to say, the citizens of a democratic state' ([1945] 1977, 1: 127). For Popper, democracy itself is apparently put beyond rational criticism. He does argue explicitly against the free market and in favor of what he calls 'protectionism', by the state, to defend freedom and welfare (for example, [1945] 1977, 1: 110-11). A comprehensive response to Popper would have to include a close analysis of such arguments. In this philosophical outline I shall have to refer the reader to the relevant social scientific literature for the evidence against such 'protectionism'. ${ }^{4}$

I shall now expand on and make slightly more precise the supposed similarities and dissimilarities in the following, somewhat schematic, list. I do not doubt that this list could be further extended, clarified, and elaborated. Points are grouped together with the same number for each (dis)similarity, for ease of comparison and criticism.

CR.: Critical rationalism (Popper's epistemology and methodology).

LL.: $\quad$ Liberty and laissez-faire (individual sovereignty and the free market).

LD.: Liberal democracy (actually existing liberal democracies rather than some impossible ideal).

CR.1. No one has the authority to establish whether a theory is true or to impose his theories on others.

LL.1. No one has the authority to establish whether a product or practice is desirable or to impose his products or practices on others.

LD.1. The state has the authority to establish and impose what it sees as desirable products and practices.

CR.2. We can be optimistic about attaining truth via free competition among theories.

LL.2. We can be optimistic about achieving welfare via free competition among products and practices.

LD.2. Political intervention is due to pessimism about achieving welfare via free competition among products and practices.

CR.3. Scientists perceive their individual problems.

LL.3. Persons and businesses perceive their individual problems.

LD.3. Governments claim to perceive collective problems for the country/nation/society/economy/public interest (all these almost invariably being euphemisms which disguise special interests).

CR.4. Scientists specialize in problems, not subjects with conventional boundaries.

LL.4. Persons and businesses specialize in their problems.

LD.4. Politicians are generalists without specialist skills - except in sophistry. 
CR.5. Scientists seek interesting and substantial truths.

LL.5. Persons and businesses seek valuable and substantial practices and products.

LD.5. Politicians usually seek votes.

CR.6. Scientists should conjecture as boldly as they can imagine.

LL.6. Persons and businesses should conjecture as boldly as they can imagine.

LD.6. Politicians must usually consider cautious, small policy variations ('extremism' will lose more votes than it gains).

CR.7. Paternalism or special interest cannot impose or restrict scientific conjecture and experimentation.

LL.7. Paternalism or special interest cannot impose or restrict individual and business conjecture and experimentation.

LD.7. Paternalism and special interest must impose or restrict individual and business conjecture and experimentation.

CR.8. Error elimination is required: so seek falsification, not ad hoc defenses.

LL.8. Error elimination is required: 'falsification' is obvious in less satisfaction or lower profits; coerced subsidies are not possible.

LD.8. Error is unclear to politicians, except in terms of lost votes. So they deny error and subsidize mistakes.

CR.9. After error elimination there is a new scientific problem situation.

LL.9. After error elimination there is a new personal or business problem situation.

LD.9. No clear new problem situation emerges, except that politicians have to buy more votes from somewhere, somehow.

CR.10. This requires a new scientific theory.

LL.10. This requires new practices and products.

LD.10. Politicians usually seek a short-term botch without a clear theory, hence testing is difficult. ${ }^{5}$

CR.11. The general social picture is of peaceful, polycentric competition among scientists about theories.

LL.11. The general social picture is of peaceful, polycentric competition among individuals and businesses about practices and products.

LD.11. The general social picture is of politically imposed privilege, predation, persecution, and Procrustean rules.

CR.12. This is against holistic (society-wide) experiments because it is impossible to understand and test with so many variables or with unique situations.

LL.12. This ensures individualism in understanding and testing personal or business problems.

LD.12. Politics is typically holistic about understanding and testing problems of 'society' and 'the economy'. ${ }^{6}$

CR.13. This is against the historicist theory that social sciences make long-term prophesies.

LL.13. This views unique individuals and the market catallaxy as unpredictable in the long term.

LD.13. Politicians often rely on historicist theories to defend both 'inexorable' change and 'unshakeable' tradition.

CR.14. This is against the historicist theory that universal (hence timeless) social scientific technology is impossible.

LL.14. This view embraces universal social scientific technology, especially from microeconomics. ${ }^{7}$

LD.14. Politicians often belittle social scientific advice, especially from (anti-political) microeconomics. ${ }^{8}$ 
Why does Popper not see that libertarianism is the better social application of his epistemology and methodology? I suggest three possible contributory factors: 1. Popper came to his political position from a socialist one and retained some sympathy for socialism. 2. He made no serious study of economics; he simply swallowed many popular anti-market prejudices. ${ }^{9} 3$. Popper thinks 'absolute freedom is impossible' ([1963] 1978, 345). Instead, following Kant, the 'liberal principle demands that the limitations to the freedom of each ... should be minimised and equalised as much as possible ...' ([1963] 1978, 351).

As (3) is the philosophical factor, let us focus on that. It is probably Popper's anti-essentialism that has caused him to avoid any explicit formulation of a theory of liberty that can be applied. But if we say, as I do, that a free person is someone who is not being imposed on by others (withholding a benefit, defending oneself, and enforcing a contract, restitution, or retribution cannot really be imposing), then it is possible to have a group of people who are completely free with respect to each other. And by such a conception of freedom it follows that state interference with non-invasive activities will be an assault on freedom.

When Popper was writing The Open Society and its Enemies he was contrasting the workings of liberal democracies such as Britain and the United States with totalitarian regimes of the kind with which they were at war. He considered the book to be his war effort. By such a contrast, liberal democracies are certainly more conducive to individual freedom and welfare, and I do not intend to contradict the general thesis for which Popper was arguing. But even if I were to agree with Winston Churchill that (liberal) democracy is the worst form of government apart from any other, I should wish to add that private-property anarchy is not as bad as liberal democracy. ${ }^{10}$

Hegel's 'principle of subjective freedom', that free speech allows people 'an irrelevant opportunity to give vent to their feelings' (as Popper interprets Hegel), seems quite realistic from a libertarian position. Popper's view that this is 'cynicism', that the ordinary man is substantially free because he can speak his mind about politics, is quite inadequate ([1945] 1977, 2: $310 \mathrm{n} 43,2$ ). The illusion that a liberal democracy constitutes a so-called free country is partially sustained by this trick, which Popper perpetuates instead of taking liberty seriously.

At the end of the addenda to The Open Society and Its Enemies, Popper states that fallibilism "can show us that the role of thought is to carry out revolutions by means of critical debates rather than by means of violence and warfare ... This is why our Western civilisation is an essentially pluralistic one ...' ([1945] 1977, 2: 396). But what is politics finally backed up by if not aggressive violence? And what could be more pluralistic than respecting individual sovereignty instead? And this liberal democracy does not do.

\section{Notes}

1 It is this last point about bold conjecture that has been mistaken as a sanction for revolutionary state experimentation. But, as dry logic and bloody history shows, such state experimentation really replaces millions of individual experiments with one Procrustean one.

2 A free science and a free society are different things, of course. I am sure it is possible to come up with some relevant disanalogies as well. I will not attempt to list all these and reply to them. This is partly because one has to stop somewhere, but more important is that I cannot think of any that seriously threaten the general thesis being defended here: full anarchic libertarianism fits Popper's epistemology and scientific method much better than liberal democracy does. I do not assert that the fit is perfect in every way.

3 To name but three who have made out general cases that private provision of law and order is not only possible but far superior: Molinari 1977 (a translation of his 1849 essay); Rothbard [1970], [1973]; David Friedman [1973].

4 The publications of the Institute of Economic Affairs (UK) are a good place to start on protectionism.

5 On this point see Robinson 1993, $11 \mathrm{ff}$. This work is a case study on state energy policy that touches on many of the points in this section. The conclusion is a succinct introduction to the economics of government failure.

$6 \quad$ So-called piecemeal engineering (Popper's expression and suggestion) by the state is simply authoritarian rather than totalitarian. 'Social planning' that is imposed by force has the objectionable character of a revolution even if it is writ small. Only genuinely peaceful persuasion along libertarian lines completely avoids the problems of state planning.

7 Microeconomics is really just economics. Macroeconomics is mainly about unsound arguments for political intervention. One brief discussion of this is area is Simpson 1994.

8 For instance, rent control and minimum wage legislation are policies that are bound to decrease welfare in the long term (though economic controversy on minimum wages has revived; see Lal 1995). Again, Popper often sees such things but fails to see that this is a practical inevitability in a vote-buying liberal democracy. 
9 This is despite the fact that Hayek's pro-market views must have had some influence on him. Conjectures and Refutations is even dedicated to Hayek.

10 Can the market itself be seen as a sophisticated and fair form of democracy (with money as a store of voting power, which is voted to one by others)? That cannot literally be true as there is no rule in the market, only voluntary cooperation. The consumer is sovereign over only himself and his purchases.

\section{References}

Molinari, Gustave de, [1849] 1977. The Production of Security. New York: Centre for Libertarian Studies.

Friedman, David D. [1973] 1989. The Machinery of Freedom: Guide to Radical Capitalism. 2nd ed. La Salle, Ill.: Open Court.

Polanyi, Michael. 1951. The Logic of Liberty: Reflections and Rejoinders. London: Routledge \& Kagan Paul.

Popper, K. R. [1945] 1977. The Open Society and Its Enemies. 2 vols. 5th ed. London: Routledge \& Kegan Paul.

— [1963] 1978. Conjectures and Refutations. 4th ed. rev. London: Routledge \& Kegan Paul.

Robinson, Colin. 1993. Energy Policy: Errors, Illusions and Market Realities. London: Institute of Economic Affairs.

Rothbard, Murray N. [1973] 1978. For a New Liberty: The Libertarian Manifesto. Rev. ed. New York: Macmillan Co. 